\title{
REGIONAL DIFFERENCES IN LAND USE IN HUNGARY
}

\section{Norbert Bozsik*, Gábor Koncz}

\author{
Eszterházy Károly University, Károly Róbert Campus, Gyöngyös, Hungary
}

\begin{abstract}
In the last decades, the area of agricultural land has been declined permanently in Hungary. Despite the diminishing production area, Hungary is among the leaders in terms of the proportion of agricultural land to the total area in the European Union. There are several reasons of using the arable land. As other economic sectors have gained a greater role in the production of GDP and employment, they have taken a larger area from agriculture. Real estate and infrastructure developments were justified by raising the standard of living of the population. The soil, nature, landscape and water protection aspects were also involved. In Hungary, the arable land is the most important natural resource, so it is very important to protect it. In our study, we examine the changes of arable land and uncultivated area in Hungary based on secondary databases of the Hungarian Central Statistical Office and departments of the Ministry of Agriculture. In the course of the research we focused on regional disparities.
\end{abstract}

Keywords: arable land, non-agricultural land use, land protection, regional disparities

The land is the resource of agricultural production. Land assets have important characteristics: scarcity (land exists only in fixed amounts), immobility, and durability. Land is a part of the national wealth and it must be used in profitable and sustainable way (Magda and Szücs, 2002). The agricultural area declined in the Europe Union in recent decades, but at a slower pace. Currently, agricultural land covers about $45 \%$ of the EU territory. The EU arable land is expected to decrease by $3 \%$ over the outlook period, and reach 104 million ha by 2030 (European Commission, 2017). This decline is attributed to the modernization and the intensification of agriculture, which allowed a decrease in land area and labour (Ramankutty and Foley, 1999). The forest degradation, was a common process in Eastern Europe during the post-Soviet era, afforestation was generally widespread throughout the majority of the region since the fall of socialism (Taff et al., 2010). Due to afforestation, the agricultural land also decreased. This trend is expected to continue. However, agriculture still has a dominant role in relation to land use and the appearance of the countryside.

The agriculture is an important economic sector of Hungary with great traditions. After the change of regime, the share of agriculture in the GDP and in the employment decreased, but after the EU accession it stopped falling. The extensification of agriculture was primarily observed in the areas of northern and central Hungary. The intensified agricultural production was typical in north eastern and central Hungary between 1990 and 2009 (Feranec et al., 2017). In recent years, the agriculture had a share of about $3-4 \%$ in the GDP and 5\% in employment. The proportion of crop output to animal output has been increasing for decades. Crop production has recovered, but animal production has continued to decrease. The main arable crops have traditionally been the cereals (wheat, maize, barley etc.), sunflower and oilseed rape (Szűcs et al., 2017). Crop production is the most important basis of agriculture and determines the competitiveness of many product chains. Besides ensuring self-sufficiency, the crops play an important role in the agrifood trade (Tikász et al., 2017).

Hungary has an area of 9,303 thousand $\mathrm{km}^{2}$. Depending on the fertility of soils, about $85 \%$ of Hungary's territory is suitable for different purposes in agriculture and forestry. The quality of cultivated lands, soil types, physical features, slope and climatic conditions are all good for agricultural production, although there are significant regional differences (Birkás et al., 2012). In 2016, the utilized agricultural area was 5.43 million ha and 1.94 million ha were covered by forests. The arable land occupied 4.33 million hectares; the fruit orchards, vineyards and kitchens totalled 235 thousand hectares. The remained areas were grassland (865 thousand hectares) (Csipkés et al., 2017). About $10-15 \%$ of the arable land is often flooded. The noncultivated area amounted to 1,927 thousand hectares. Between 1990 and 2016 , the uncultivated areas increased from $11 \%$ to $22 \%$, to the detriment of agricultural lands and green areas (grasslands, gardens, vineyards, orchards, arable lands) (Department of National Parks and Landscape Protection, Ministry of Agriculture 2017).

The land utilisation can be defined as a fine balance between sophisticated and inter-related activities, a precise order and harmony of biological, physical and chemical processes (Magda, 2007). The changes in land use can be interpreted as changes in the resources, services, and goods that soils offer to us; moreover, the type of land use change varies among different types of regions (Aksoy et al., 2017).

The area in all agricultural land-use categories decreased, while the area in other categories (forests, reeds and fishponds) increased in the past decades (Hungarian Statistical Office, 2017). The decline of land use for food production can be attributed to different reasons. The external factors include the land withdrawal from cultivation and the internalization of arable land. The reason for withdrawal is the artificial land development (as transport, infrastructures, and construction sites), that is a threat to agricultural land. When the investments are set up, preserving of soil quality is not important.

The internal factors include the planned and spontaneous afforestation, as well as the establishment of energy plantation. The agricultural area of Hungary decreased; meanwhile, the area of forests has been continuously growing. The area of forests increased by 245,000 hectares between 1990 and 2016, which reduced the amount of areas used for food production by the same amount. In addition to the planned afforestation, a great part of the uncultivated land was spontaneously forested due to the disorder of ownership. Hereby, it must be 
noticed that when Hungary joined the European Union (in 2004), foreign citizens could not purchase land in Hungary. The moratorium forbidding the purchase of arable (agricultural) land by foreign citizens and legal persons in Hungary expired in 2011, then it was postponed by 3 years until 2014 (Téglási 2012). The planting of forests for energy production also reduces the areas suitable for food production. According to experts, in the long run 300-400 thousand hectares of plantation for energy production could be realized in Hungary (Póliska 2012).

\section{Material and methods}

The research concentrates on land use. We considered the aspects of investors and land protection for a reasonable resource management. One of our research objectives was to examine the change of arable land in Hungary. Subsequently, we examined what regional differences can be detected at the county level. We reviewed the specificities of all counties, correlated with their social, economic and environmental characteristics.

Our analyses were based on secondary databases. The data of land use categories are available according to a unified methodology on the website of Hungarian Central Statistical Office. The data about conversion of agricultural land to non-agricultural use are collected at the Department of Land Administration and Geoinformatics in the Ministry of Agriculture. Based on these databases we could examine the distribution of new, uncultivated land from perspective of former land use categories and new functions between 2010 and 2015. In most cases the analysis was performed with simple distribution tests. The exploration of differences among the counties was supported by editing thematic maps.

\section{Results and discussion}

In the past decades, the area of the arable land has been continuously and significantly decreasing in Hungary. After 2010, this downward trend slowed down and stopped. The decline was consolidated around 2012 as a result of an ever-expanding and improving rural development strategy. The agricultural area decreased from about 6.47 million hectares to 5.35 million hectares between 1990 and 2017 (Table 1). During this period, the decrease of productive land area was lower compared to agricultural areas (8.24 million hectares to 7.37 million hectares), due to the expansion of forest areas. Thus, during 27 years, the area of uncultivated land increased from 1 million hectares to over 1.9 million hectares.

In the category of grassland, the decrease was higher than in case of arable land. This is consistent with the fact that the livestock population has declined significantly in Hungary. After 2015, there is a significant decline in the category of small (cannot be cultivated by large scale methods) gardens located near to populated areas. As these properties no longer occupy an

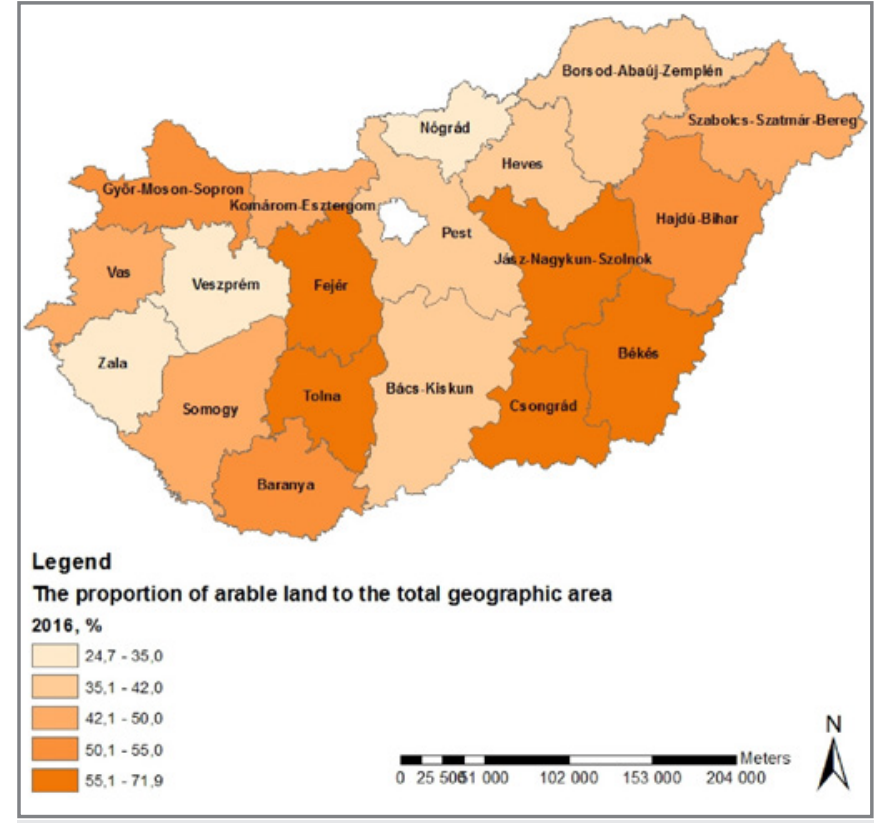

Figure 1 The proportion of arable land to total geographic area (2016) in \%

Source: Own editing based on data of Hungarian Central Statistical Office (2016)

agricultural function, they rather have a living, resting, and green belt orientation. Therefore, the Land Protection Act does not apply to them.

The proportion of arable land to the total area in Hungary was 46.6\% (2016). There are no higher mountains in Hungary. However, there is a significant difference between the land use of counties dominated by hills and mid-mountainous areas and counties dominated by well-grounded lowlands with good soil conditions. The share of arable land is typically below $40 \%$ in the first group of counties and above $55 \%$ in the other counties (Figure 1). The decline in arable land was the most significant in those counties, where the rate is low anyway due to unfavourable circumstances. In these areas, it is not possible to compete with domestic and European competitors.

The area of the non-agricultural land has grown almost all over Hungary. The proportion of the country's forest areas increased from $18.2 \%$ to $20.9 \%$ between 1990 and 2016. The share of forests is above $30 \%$ in mountainous and hilly counties while in some lowland counties this rate is under $10 \%$. The share of the forest is also above $20 \%$ in the counties of the Hungarian Great Plain where sandy soils with worse quality are dominant. Forests are not only for the production of wood but also for various protection and recreational purposes, so their importance grows nationwide. Changes are especially noticeable in the data of traditionally less afforested counties.

Table 1 Land use trends in Hungary (1990-2017)

\begin{tabular}{|c|c|c|c|c|c|c|}
\hline Year & $\begin{array}{l}\text { Arable land } \\
(1,000 \mathrm{ha})\end{array}$ & $\begin{array}{c}\text { Garden } \\
(1,000 \text { ha) }\end{array}$ & $\begin{array}{l}\text { Grassland } \\
\text { (1,000 ha) }\end{array}$ & $\begin{array}{l}\text { Agricultural land area } \\
\qquad(1,000 \mathrm{ha})\end{array}$ & $\begin{array}{l}\text { Productive land } \\
\text { (1,000 ha) }\end{array}$ & $\begin{array}{l}\text { Uncultivated land } \\
\qquad(1,000 \text { ha })\end{array}$ \\
\hline 1990 & $4,712.8$ & 341.2 & $1,185.6$ & $6,473.2$ & $8,235.8$ & $1,067.5$ \\
\hline 1995 & $4,715.9$ & 90.2 & $1,148.0$ & $6,179.3$ & $8,010.5$ & $1,292.5$ \\
\hline 2000 & $4,499.8$ & 101.6 & $1,051.2$ & $5,853.9$ & $7,715.5$ & $1,587.5$ \\
\hline 2005 & $4,513.2$ & 95.9 & $1,056.9$ & $5,854.8$ & $7,787.1$ & $1,516.3$ \\
\hline 2010 & $4,322.1$ & 81.5 & 762.6 & $5,342.7$ & $7,356.4$ & $1,946.9$ \\
\hline 2015 & $4,331.7$ & 80.5 & 761.5 & $5,346.4$ & $7,387.6$ & $1,915.8$ \\
\hline 2017 & $4,334.3$ & 47.3 & 803.8 & $5,352.2$ & $7,370.6$ & $1,932.8$ \\
\hline
\end{tabular}

Source: Hungarian Central Statistical Office (1990-2017) 


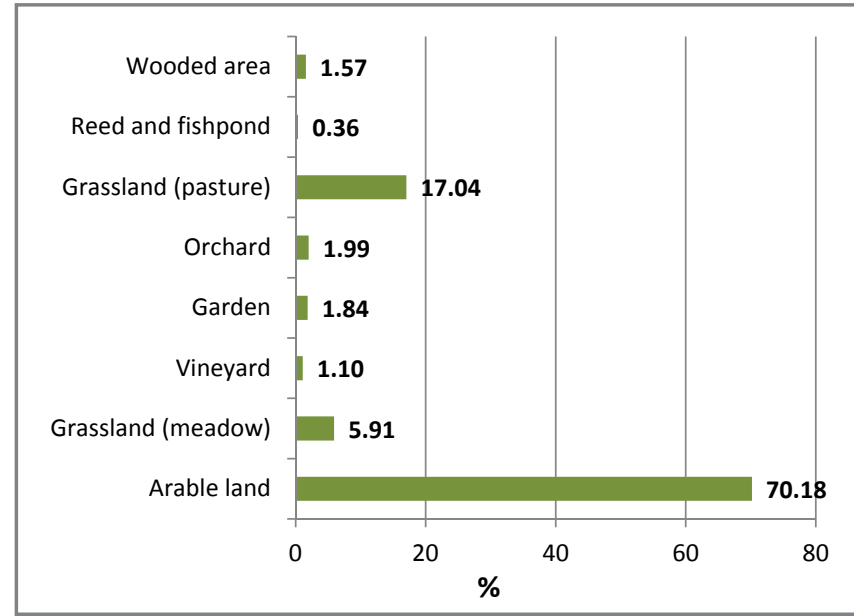

Figure 2 The distribution of land use categories within new uncultivated land area in Hungary (2010-2015)

Source: Own editing based on data (2010-2015) of Department of Land Administration and Geoinformatics in the Ministry of Agriculture

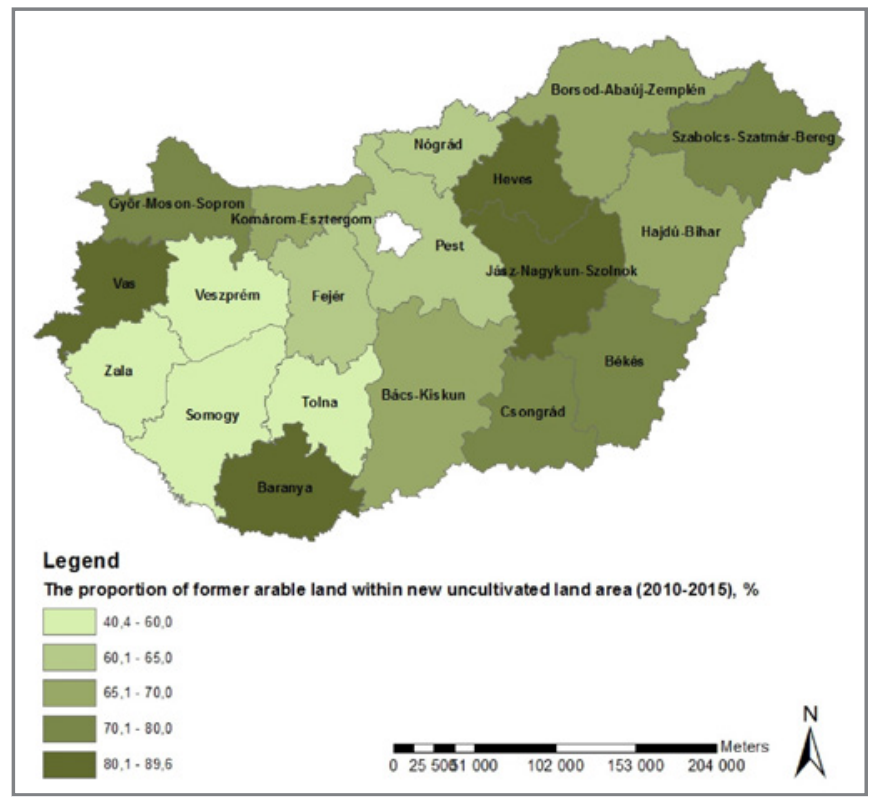

Figure 3 The proportion of former arable land within new uncultivated land area (2010-2015) in \%

Source: Own editing based on data (2010-2015) of Department of Land Administration and Geoinformatics in the Ministry of Agriculture

The proportion of uncultivated area scattered within wide limits, which is influenced by the degree of urbanization along the natural geography environment. Following the administrative area of the capital, the presence of uncultivated land is the highest in the counties characterized by significant industry and extensive mining areas. Among the provincial counties, the Jász-Nagykun-Szolnok County has the highest (nearly 29\%) and the Tolna County the lowest (barely 9\%) value. At the same time, it can be stated that in some counties the process has been reversed and the area of uncultivated lands has decreased.

In Hungary, 16177 ha of agricultural area received permission for conversion to non-agricultural use between 2010 and 2015. The size of the affected area exceeded 1000 hectares in six counties (Pest, Bács-Kiskun, HajdúBihar, Borsod-Abaúj-Zemplén, Baranya, Győr-Moson-Sopron). These are partly the largest counties in Hungary. On the other hand, the Pest County includes the rapidly developing settlements of the metropolitan agglomeration. Bács-Kiskun and Györ-Moson-Sopron have significant automotive industry sites. However, in the Baranya County, $65 \%$ of the affected areas were without defined use. The area of new uncultivated lands is between 500 and 1000 hectares in most of the counties over the six examined years. The Tolna County was the least affected in the process, the converted area did not reach 100 hectares.

Industrial development, urbanization and the development of transport also require new areas. According to experience, this demand can only be met at the expense of agricultural land. The problem is that primarily not the agricultural lands with weaker quality are extracted from cultivation. Since the most suitable areas for construction are those that are flat or slightly sloping, there is a sufficient depth of groundwater that does not contain harmful salts, that is to say, the most suitable for agricultural cultivation. According to this, the proportion of former arable land within new uncultivated land area (2010-2015) is much higher in the decisive part of the country than the importance of arable land in land use. This is $70.18 \%$ of the national average (Figure 2), but in four counties it is over $80 \%$ (Figure 3).

As previously mentioned, the various branches of economy are competing for the best productive areas. However, there are land use methods (e.g. mines, landfills, defense functions) which are less tied to the proximity of cities or motorways. Therefore, the conversion affects area with more extensive agriculture in a higher proportion. The share of grasslands is nationally $23 \%$ but it exceeds $40 \%$ in 5 counties (Tolna, Veszprém, Nógrád, Somogy and Fejér).

The proportion of the smaller and intensive cultivation branches is low but higher than their significance in land use. The reason for this is that in many cases, orchards and vineyards are in the way of expansion of expectations. The former gardens were replaced by housing estates in several cities some decades ago. Forests are planted for a long period, therefore, their importance is small. Of course, the wetlands represent the target area of investments in the rarest of cases.

Among the arable lands that have a new function the role of infrastructural developments (26.23\%) is the most important one nationwide. The expansion and construction of infrastructure has affected more than 300 hectares in four counties (Hajdú-Bihar, Bács-Kiskun, Gyôr-Moson-Sopron and Somogy). The proportion of agricultural investments, borrow area and mines are also above 10\% (Figure 4). However, the development of residential areas does not account for $5 \%$. This can be related to the unfavourable demographic processes of the country.

The primary objective of economic development has been the establishment of manufacturing sites in recent years. The number of industrial

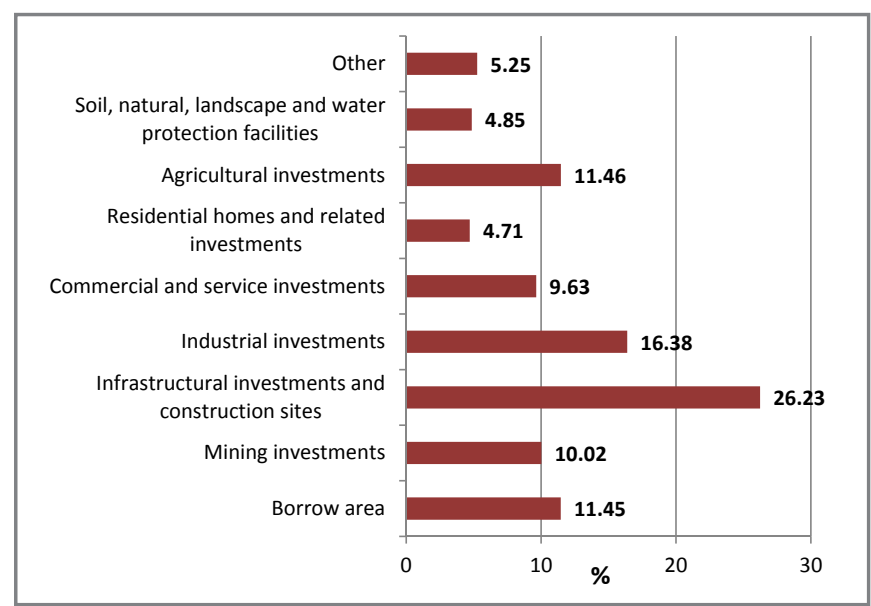

Figure 4 The distribution of new functions of former agricultural lands (based on area) (2010-2015) in \%

Source: Own editing based on data (2010-2015) of Department of Land Administration and Geoinformatics in the Ministry of Agriculture 


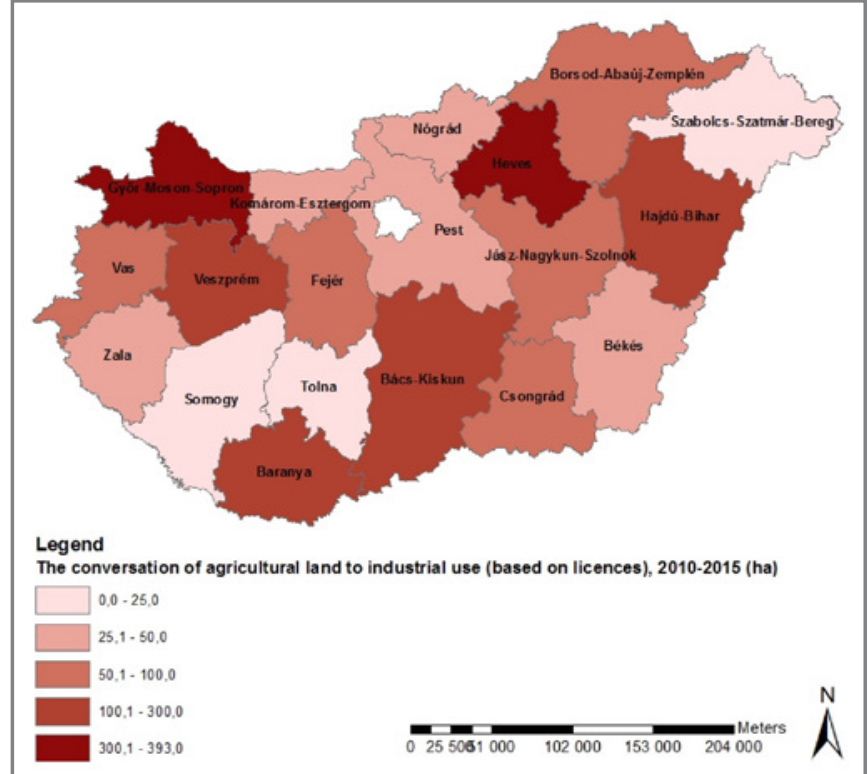

Figure 5 The conversion of agricultural land to industrial use (based on licences), 2010-2015 in ha

Source: Own editing based on data (2010-2015) of Department of Land Administration and Geoinformatics in the Ministry of Agriculture

parks is 196 in Hungary, but much more towns and villages are looking for industrial investors. The map (Figure 5) points out that there are significant territorial differences between the counties' capability to attract capital. The Györ-Moson-Sopron County is in the best position, due to the most favourable geographical location among counties (the closest to Western Europe), the industrial traditions and earlier major investments that were successful. In recent years, the situation of the Heves County is also favourable, as it has a relatively good geographic position in the eastern half of the country.

The agricultural investments are concentrated on the lowland counties with best relief and soil conditions. In the case of mining investments, the role of mountainous areas is not decisive, but hydrocarbon well sites in the lowland area. The commercial and service investments are attracted by major consumer markets and solvency demand. Therefore, the most investments are realized in the metropolitan areas and other prosperous cities. The main destinations of newly built residential areas are thePest County (Budapest agglomeration), the Bács-Kiskun County and the Hajdú-Bihar County. The underdeveloped peripheral counties of the country are afflicted by significant emigration, so there is no need for substantial residential development.

\section{Conclusions}

The land is one of the most import resources of Hungary. The condition of the long run sustainable agriculture, to fit in with the environment, which means to use the land for those production and so intensity which will be the most optimal utilisation. In the last decades, the structure of land use significantly changed, the area in all agricultural land-use categories decreased. The decline of land use for food production can be attributed to the land withdrawal from cultivation and the afforestation of less fertile agricultural land. After 2010, the expansion of the uncultivated land decreased due to successful land protection. It is unfavourable, that the withdrawals from cultivation mostly happened in high quality lands that are very close to settlements.

There are significant differences in the structure of land use in the counties with different natural resources in Hungary. The regions that have high-quality soil were less affected by the change in land use within the agricultural sector, however, in these regions, the need for land of the industry and service sector is very significant. After 2010 the degree of the withdrawn areas has been influenced by these needs. In these areas, mostly infrastructure investments were implemented. The industrial investments were concentrated in some counties. The service sector and real estate developments are concentrated in the metropolitan agglomerations. In the future, the less favoured and underdeveloped peripheral areas should be preferred for greenfield investments.

\section{References}

AKSOY, E. - GREGOR, M. - SCHRÖDER, C. - LÖHNERTZ, M. - LOUWAGIE, G. 2017. Assessing and analysing the impact of land take pressures on arable land. = Solid Earth, vol. 8, 2017, pp. 683-695.

BIRKÁS, M. - JOLÁNKAI, M. - MESIC, M. - BOTTLIK, L. 2012. Soil Quality and Land Use in Hungary, 2012, p. 15. available: https://bib.irb.hr/datoteka/572537.1._9-23.pdf

CSIPKÉS, M. - NAGY, L. - SZABÓ, K. 2017. Magyarország földhasználatának elemzése rendszerváltástól napjainkig. In Jelenkori Társadalmi és Gazdasági Folyamatok, vol. 12, 2017, no. 1-2, pp. 141-152.

DEPARTMENT of National Parks and Landscape Protection, Ministry of Agriculture 2017. National Landscape Strategy (2017-2026).

EUROPEAN COMMISSION 2017. EU Agricultural ooutlook for the EU Agricultural Markets and Income 2017-2030. pp. 90

FERANEC, J. - SOUKUP, T. - TAFF, G.N. -STYCH, P. - BICIK, I. 2017. Overview of Changes in Land Use and Land Cover in Eastern Europe. available: https://www.researchgate. net/publication/310540496_0verview_of_Changes_in_Land_Use_and_Land_ Cover_in_Eastern_Europe

HUNGARIAN Central Statistical Office database. 2017.

MAGDA, R. - SZŰCS, I. 2002. Új irányzatok a földhasznositásban. Budapest : Agroinform Kiadó; Stratégiakutató Intézet, 2002, 151 p.

MAGDA, R. 2007. Changes in land utilization in Hungary since the transition. Plenary paper prepared for presentation at the joint IAAE $-104^{\text {th }}$ EAAE Seminar Agricultural Economics and Transition: "What was expected, what we observed, the lessons learned." Corvinus University, 2007, p. 11.

PÓLISKA, CS. 2012. Fás szárú energianövények szerepe kistelepülések hőenergia ellátásában. In Anyagmérnöki Tudományok, vol. 37, 2012, no. 1, pp. 331-342.

RAMANKUTTY, N. - FOLEY, A. J. 1999. Estimating Historical Changes in Global Land Cover: Croplands from 1700 to 1992. In Global Biogeochemical Cycles, vol. 4, 1999, no. 13, pp. 997-1027.

SZÜCS, CS. - VANÓ, G. - KORSÓS-SCHLESSER, F. 2017. Agricultural and Food Production in Hungary: on the Road to Sustainability. In Visegrad Journal on Bioeconomy and Sustainable Development, vol. 2, 2017, pp. 59-63.

TAFF, G.N. - MÜLLER, D. - KUEMMERLE, T. - OZDENERAL, E. - STEPHEN, J. - WALSH, J.S. 2010. Reforestation in Central and Eastern Europe after the breakdown of socialism. In Nagendra, H. - Southworth, J. (eds) Reforesting landscapes: linking pattern and process. Springer Landscape Series, Dordrecht, 2010.

TÉGLÁSI, A. 2012. The protection of arable land in the basic law of hungary with respect to the expiring moratorium of land acquisition in 2014. In Kotásek, J. - Bejček, J. Kratochvíl, V., Rozehnalová, N. - Mrkývka, P. - Hurdík, J. - Polčák, R. - Šabata, J. (ed.). VI. ročník mezinárodní konference Dny Práva 2012. Brno : Masarykova Univerzita, 2012, pp. 2442-2465.

TIKÁSZ, I. - BENE, E. - KRIZOVÁ, S. - NOVOTNY, P. 2017. Competitivenes of Crop Production. In BíRÓ, SZ. (ed.) 2017. Structural Changes in Agriculture since EU Accession in Slovakia, the Czech Republic and Hungary. In Research Institute of Agricultural Economics, 2017, pp. 51-74.

\section{Contact address}

Norbert Bozsik, college professor

Eszterházy Károly University

Faculty of Economics and Social Sciences

Mátrai str. 36, Gyöngyös 3200, Hungary

e-mail: bozsik.norbert@uni-eszterhazy.hu 